\title{
Jogo de contrários
}

Vilma Arêas *

\author{
La liberté du poète n'est donc que son \\ bistoricité. Non liberté de choix. Mais \\ l'imposition de l'altérité
}

Henri Meschonnic

A agitação provocada por este Elefante nos meios literários brasileiros foi surpreendente. ${ }^{1}$ Então a poesia é capaz ainda de causar rebuliço? Publicado em novembro de 2000, emite até hoje suas faíscas. Se as razões das desavenças nem sempre eram, ou são, literárias, por outro lado - e é isto que me interessa - a perturbação causada pelo livro explica-se pela complexidade das questões que levanta. De outro modo, como entender a impaciência diante de uma obra amadurecida formalmente num processo lento e conseqüente, preocupada além disso com as questões brasileiras? Surgida no contato com as grandes correntes do modernismo, sejam Pound, Eliot, Pessoa, sejam Bandeira e Drummond, temperou-se com a "poesia marginal" dos anos 70, sem deixar de estar atenta às gerações mais novas.

Adiantando conclusões, diria que algumas razões do estranhamento que o livro causou repousam na identificação de procedimentos formais, que entretanto provocam efeito inesperado no leitor. $O$ famoso poema-piada, por exemplo, de corte modernista e usado por Oswald de Andrade com sentido crítico eufórico, produz aqui um sentimento de mal-estar, pois não houve mudança substantiva no país, se riso há, tratase de "riso torto".

Uma outra causa de estranhamento talvez dependa da estrutura polarizada do conjunto dos textos, obedientes ao comando da tradição poética culta, onde circulam os poemas líricos, estando ao mesmo tempo à escuta do registro idiomático ou familiar da língua, camada que concen- 
tra certa experiência histórica e social brasileira. Não se trata da mescla de registros, uma conquista da modernidade, mas de surpreender a fala em situação, como se se tratasse de teatro, interagindo de forma incomum com os outros textos.

A conseqüência da aparente inflexibilidade dessa cisão reflete-se também na divisão da crítica, que em geral se deteve em um dos dois registros, desequilibrando a interpretação.

No entanto, meio século atrás Adorno ${ }^{2}$ já estabelecera o caráter dúplice da voz lírica: se ela não se resume ao mero registro da experiência individual, também não serve como demonstração de teses sociológicas. Ao contrário, é através de sua especificidade formal, do seu "tomarforma estético", que a lírica mergulha no próprio fundamento. Em outras palavras, será a densidade da individuação o que paradoxalmente permitirá à voz lírica fazer soar "o sussurro da vida civil”, na expressão de Manuel Bandeira.

O recurso utilizado por Alvim - o da aparente divisão dos registros - pode levar o leitor a concluir pelo caráter despropositado dessa alteridade. Estaria assim fatalmente fracassada a mediação formal imprescindível à integridade da forma artística, principalmente quanto às peças teatralizadas, que naufragariam, enquanto lírica, pelo apagamento do sujeito lírico.

No entanto não se trata aqui de um sujeito "não constituído". Às vezes ele irrompe com inegável decisão. Observe-se abaixo o poemadeclaração-de-princípios, ou poema-prova-dos-nove, já que vem na parte final do volume:

\section{Conversa de Alice com Humpty Dumpty}

- A questão é de saber

se uma palavra pode significar tantas coisas

- Não, a questão é de saber

quem manda 
O poeta, portanto, ordena que se misturem neste Elefante vôo lírico, marca de individuação da voz, e a ameaça de sua diluição, pela proximidade perturbadora da fala coletiva, socialmente cristalizada. Funciona aqui o poeta como regente ou diretor-de-cena, escondido nas coxias, momentos em que assistimos a esse aparente auto-esquecimento do sujeito. Sublinho esse caráter de aparência, pois o que na verdade temos, retomando o paradoxo freudiano, é um sujeito distraidamente atento, às vezes extraviado (confira-se "Escolho"), que observa de perto as situações e o modo pelo qual existem, a partir da investigação das possibilidades de sentido das palavras cotidianas. Se tal sentido obedece à expressividade que evita a notação exata, sua flutuação na fala não é arbitrária. Ao contrário, ajusta-se como uma luva ao feitio equívoco ou dissimulado do autoritarismo brasileiro. Ora, estabilizar de algum modo o sentido, mostrar o que as palavras dizem, exige uma escolha ("quem manda"), com a ajuda da referência. Esta é uma das lições deste Elefante.

Assim é que as vozes em ação, ora iluminam circunstâncias constrangedoras da história nacional, resistentes ao passar do tempo, ora soam pungentes, costeando o drama, às vezes polvilhadas de ironia; constituem o único rastro das personagens que passam invisíveis: acidentados, moribundos, morta velada por futuro suicida, velhos e mais velhos com sua "dorzinha" que não passa, um travesti, mulheres oprimidas (o poema sobre a mãe intitula-se "Mula"), abandonados, exploradores e explorados, solitários, amantes desencontrados, bêbados pobres e ricos, e assim por diante.

É nesses poemas que a preocupação ética do escritor encontra sua expressão mais convincente, atenta às injunções indecorosas de nossa formação.

Frases feitas, expressões escandalosamente elípticas, às vezes o clichê, compõem essas pequenas cenas soltas nas quais o leitor de saída derrapa (o que será que isto realmente significa?). Elas existem num espaço comunitário povoado, horizonte da experiência da solidão individual. A melancolia que esta destila em sua reclusa subjetividade deita raízes 
profundas na esfera do espaço público, no qual o drama é desvestido da grande retórica e entregue à banalidade da expressão humilde. Que esses registros dividam democraticamente o espaço da página, mascarados além disso na incompatibilidade dos gêneros, eis o que talvez tenha desnorteado alguns críticos.

As expressões idiomáticas (de classe, de família, de época) que amparam as situações, ou meras frases soltas, pois toda perenidade é acompanhada, no livro, pelo que é efêmero, compõem todas juntas, portanto, uma espécie de chão para a harmonia da construção poética como um todo, cujos alicerces e possibilidades/impossibilidades semânticas são postos a nu.

Os pequenos episódios "desentranhados" dos acontecimentos comuns copiam dessas expressões fixas o corte sintético, mas também o caráter furta-cor e metafórico da fala e da gíria. Por exemplo, "mula" é o animal ou o transportador da droga? A que ou a quem se refere o poema "Selas"? "Escolho" é o verbo ou o substantivo? Quem exatamente fala nos diálogos? Ao leitor não é dada qualquer ajuda, mas é neste preciso instante, observa Antônio Carlos de Brito, ${ }^{3}$ que o poema desliza da objetividade para processos subjetivos, realizando-se a transcendência poética. A verdade do poema parece então "flutuar sobre um poço sem fundo".

Por isso faz-se necessária toda a atenção para não cairmos pelos desvãos ou tropeçarmos em certas artimanhas lingüísticas responsáveis pela oscilação do sentido.

Por exemplo, no poema

Mas

é limpinha

que omite a primeira parte de um sintagma absolutamente familiar para os brasileiros, pronunciado no momento em que uma patroa branca contrata uma doméstica parda ou negra - "é preta mas é limpinha”, reza 
a frase completa -, o diminutivo desliza da pessoa para sua insignificância social. A expressão na verdade significa "preta de alma branca". Isso explica o deslocamento da frase para outras circunstâncias de desclassificação social. Ao contrário do sentido desse diminutivo, a "dorzinha" que tortura o velho em mais de um poema, íntima do corpo e insistentemente dolorosa, ganha foros de aumentativo ou intensivo. Com isso quero dizer que as semelhanças são quase sempre diferenças. Nos exemplos acima, o primeiro diminutivo aponta a "voz coletiva", automatizada e quase inaudível - pela repetição do uso - quanto a seu sentido profundo, que é recolocado pelo poema a partir da mutilação da expressão completa, gesto que a desautomatiza e manda que ouçamos realmente o que ela significa, o que a ideologia esconde. Por outro lado, a intensidade do segundo diminutivo sinaliza para a intransferível experiência individual, substância trabalhada nos poemas líricos.

Das pecinhas ou "narrativas comunitárias" quebradas fazem parte (1) expressões altamente inventivas, estruturalmente correspondentes, no outro plano, à imagística lírica; são por isso mesmo intraduzíveis, bafejadas pelo que o poeta chama "gênio" da(s) língua(s) (confira-se "Desceu bem", certamente só compreensível para um brasileiro, fazendo par com expressões espanholas, também intraduzíveis); (2) citações de vária extração e em várias línguas, unindo no mesmo fio o perfil funesto do mundo de hoje, o "deserto" tantas vezes lembrado a partir do poema de abertura, e um mundo extinto, cujos destroços bóiam na página ("oh!, que famintos beijos na floresta"). "Com ninguém" oferece um exemplo acabado dessa situação; (3) farrapos de frases ouvidas em circunstâncias várias no Brasil e em outros países e que funcionam também como marcação de ritmo; (4) esquemas lógicos pela metade, brincando com a filosofia, além disso construídos em direção contrária, fiel, portanto, à etimologia de "verso" -

: o ser humano é o seguinte 
A esse ponto, recuperando-se de uma espécie de tontura, o leitor é instado a encontrar o lugar justo dos versos. Mas serão mesmo versos? Ou coisas versáteis que não cessam de mover-se ao menor sopro - este mesmo que "venta" sem interrupção nas páginas?

Creio que a solução mais simples para a harmonização desses registros contraditórios será confiarmos nas palavras de Alvim em entrevistas e prefácios a livros alheios. Em Entre a carne e o sonbo, comentário a "Questo frutto altro", de Maria Lúcia Verdi, ${ }^{4}$ diz ele: "A poesia quer tudo, porque pode tudo. $\mathrm{O}$ direito e o avesso. O dizível e o indizível. É tão desejante a poesia e tamanho o seu poder, que ela pode até mesmo o não - querer, o não - poder. E este jogo de contrários, de triunfo e fracasso no dizer, está em todo o poema e em cada uma das partes - concretudes, abstrações - que o conformam".

No entanto, esse jogo de contrários não necessita do conforto da citação fora do livro. Ele repousa nas tendências subterrâneas que regem toda linguagem e nos é demonstrado a partir da malha fina da construção dos poemas, no momento em que um ou outro truque é desfeito, sublinhando a interdependência das partes nos domínios da prática textual. Olhemos, por exemplo, dois poemas em páginas seqüenciais, um "baixo", outro "alto", mas um ao lado do outro precisando o mútuo sentido:

\title{
Arquivo
}

não pode ser de lembranças

\author{
Aberto \\ Para Cacaso \\ As vezes o olhar caminha \\ na trama da luz. \\ sem curiosidade alguma \\ qualquer devaneio \\ Vai em busca do tempo \\ e o tempo, como o sempre, \\ vario de tudo
}




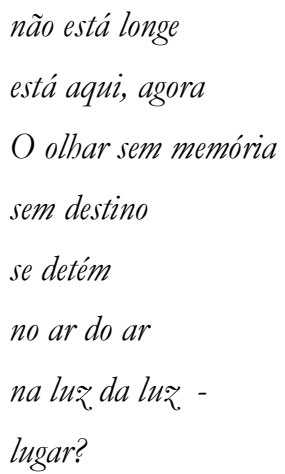

Gentilmente os poemas estão lado a lado, de forma que a definição peremptória da palavra arquivo, móvel para guardar documentos, definido pelo avesso ("não pode ser de lembranças"), ilumine o lugar adequado, embora fluido, do segundo poema, perdido no jogo rítmico (contra a clara redondilha do primeiro), vazio, impossível de definição peremptória (a própria palavra "lugar" está em forma interrogativa). É aí que "se guardam" as lembranças do amigo morto, nesse arquivo "aberto", não defendido, não cicatrizado. O poema retoma e se distancia do que escreveu um dia Drummond ${ }^{5}$ a Mário de Andrade, em idêntica circunstância ("[...] tua lembrança/ fichada nos arquivos da saudade") e é um dos exemplos da relação profunda de Alvim com o poeta itabirano, do qual se aproxima e se afasta, deixando na página esses rastros finos.

Outros procedimentos mais sutis enlaçam as partes do livro. Um deles o jogo rítmico - apoiado na redondilha, embora a cada momento o poeta insira variações - aliás como Carlos Drummond de Andrade. Obedecendo ou não ao movimento "natural" da língua, todos os textos possuem elaboração rítmica sofisticada e também seus ruidos. Por sobre o baixo-contínuo das repetições e, nos poemas líricos, repetições quase das mesmas imagens, ouvimos variações tonais às vezes dissimuladas, "notas soltas", mas com funcionalidade no conjunto: "Tetéia", por exemplo: "Quem te deu este brinquinho?/ Comprei lá na feira do Gaminha". Quase além de nossa percepção, a leveza e a afetividade destilada pelo 
diálogo constroem uma pausa entre os indigestos - por razões diferentes - "Um amigo meu" e "Monocórdio".

Em Alvim o impulso para a experimentação é grande e este prefácio não será o lugar adequado para exemplificações minuciosas das variações mínimas dos versos e dos títulos-versos, que dão a cada poema um recorte circular e paradoxalmente em aberto, na medida em que um repercute no outro permitindo à energia - ao movimento - propagar-se na contínua oscilação dos comprimentos de onda, que alcançam muitas vezes camadas imponderavelmente finas.

Entretanto, se a "lei das alternâncias" constitui formalmente este Elefante, seja na mímese sonora, seja no jogo subjetividade/objetividade que define toda linguagem, podemos nos perguntar se nessas constantes polaridades em diálogo (luz, água versus sombra, escuridão / lago versus montanha / longe versus perto/ dentro versus fora / frustração versus perenidade do desejo) não existe repouso ou harmonia. Numa só palavra, se não haverá conciliação desses opostos, alguns a pique de desaparecer dissolvidos no tempo - que ganha foros de personagem, deslocando e consumindo coisas e seres que a si mesmos se consomem, à semelhança do próprio mar "engolindo-se azul" em "Carnaval”, esta nova versão do "Canto esponjoso" drummondiano.

Eu diria que tal conciliação, que abraça todas as contradições, só pode ser encontrada na solução formal do livro, expondo os laços profundos que unem voz coletiva e voz individual. Como tentei mostrar, essa relação não vem simplesmente tematizada, o que seria simples, mas cristaliza-se nas passagens entre os pólos, no feitio que toma a imanência-transcendência da forma, que erra do constrangimento lingüístico à liberdade da imagem lírica. Esse paradoxo será o que permite seja superada, mas não descartada, a divisão entre gesto coletivo e expressão individual, entre contingência e liberdade, atingindo-se assim um ponto de chegada, a explicitação - o fio do olhar - do jogo lírico, com a mediação das imagens. 
A esse respeito, "Poema", dedicado a Carlos Drummond de Andrade, fornece as referências possíveis, mobilizando todos os elementos em suas várias formas (a água aparece como lago, açude, mar, nuvem) e convulsionadas pelo "vento" (de águas, de astros) como sombras; estas são entretanto estabilizadas pelo eixo da "coluna sonora" do poema, que soluciona o jogo dos contrários. Observemos as três últimas estrofes:

\author{
São feitas - as sombras - de ar \\ escuro \\ Lembram o tudo e o nada \\ O vôo das sombras \\ gira em torno de uma coluna \\ sonora, o poema - \\ luz de dentro \\ Fora
}

O poema homônimo do livro concentra, por sua vez, esta mesma imagem. Trata-se de um elefante-cosmogônico ao mesmo tempo material (carne) e imaterial (de ar escuro) e que mantém e ultrapassa elementos e referências humanas (anoitece pedra e vento, enfurece distância e tempo); em seu interior está o céu, o firmamento, "incêndio de pilastras", que "rui por dentro" e cujo "brilho baço" seu exterior deixa entrever.

À sua volta tudo canta.

Tudo desconhece

Assim reza a última estrofe do poema, certamente impulsionado pelas contradições do animal: imenso e ao mesmo tempo delicadíssimo (“dançarino”), composto de matéria e ar. 
Quem conhece a poesia de Francisco Alvim sabe que ele vem polindo pacientemente as imagens de seu universo; tais imagens, como as expressões da língua, possuem também uma longa tradição. Nos poemas elas se concentram em vez de se dissiparem, afinam-se e enriquecem-se no jogo das correspondências, e no sentido adicional que adquirem (refractam-se, verbo constante) através da reiteração das marcas. Música de câmara.

Se já sabemos, pelo menos desde a lição de "Ângela” (Passatempo), que o amor é água, não será surpreendente a visão de amantes mergulhados na água (também luz) ou a ela referidos, conforme acontece em vários poemas e também em "Canção", que forma uma tríade com "Elefante" e "Poema". Pois "Helóisa" ou "Heloísa" (com a alternância maliciosa da posição do acento) é também feita de "ar escuro", realiza o erotismo delicadamente sugerido em "Elefante", concretizando-se no abraço da terra e do mar.

Em "Com ninguém" a Ilha dos Amores camoniana tem seu único verso ("Oh, que famintos beijos na floresta") rematado por "frustration at your fingertips", mas realiza-se em "Canção", como no Canto IX, a utopia da união dos elementos ou dos seres incompatíveis (a ilha e o mar), talvez porque apenas "pintados", assim como a errática Ilha dos Amores é "angélica pintada". (Que não se perca a sugestão de "Céu", logo a seguir.)

É este o "real da poesia" buscado pelo poeta desde "Carnaval", chave que abre o livro. Contra a "fantasia" do mundo, que no outro registro pode ser lida como alienação, e contra a "água" transformada em terra estéril, defende-nos o "escudo" de "brilho baço" deste Elefante feito de palavras. Também da palavra carne.

\section{Notas}

* Prefácio à edição portuguesa de Elefante, a sair pela Angelus Novus. 
1 Cf. , entre outros, Paulo Franchetti, “O 'poema-cocteil' e a inteligência fatigada" $(O$ Estado de S.Paulo, 5 nov. 2000); Carlito Azevedo, "Imagens dissonantes" (Idéias Livros Jornal do Brasil, 10 nov. 2000); Flora Sussekind, "O real da poesia" (Mais! - Folha de S.Paulo, 19 nov. 2000; Roberto Schwarz, "Elefante complexo" (Jornal de resenhas - Folha de S. Paulo, 10 fev. 2001) e "O país do elefante" (Mais!, Folha de S. Paulo, 10 mar. 2002).

2 Theodor W. Adorno, "Discurso sobre lírica e sociedade", in Theodor W. Adorno et alii, Textos escolbidos (trad. Modesto Carone, Roberto Schwarz et alii). São Paulo: Abril Cultural, 1980 (Os Pensadores).

3 Antônio Carlos de Brito (Cacaso). Não quero prosa. Rio de Janeiro/S. Paulo: Editora UFRJ/Editora da Unicamp, 1997.

4 Maria Lúcia Verdi, Questo frutto altro/Este fruto outro. Ila Palma: Prudentia Editrice, 1993.

5 Carlos Drummond de Andrade, "Mário longínquo", in Lição de coisas (Poesia completa e prosa). Rio de Janeiro: Nova Aguilar, 1977. 